\title{
Effects of decontaminated fish oil or a fish and vegetable oil blend on persistent organic pollutant and fatty acid compositions in diet and flesh of Atlantic salmon (Salmo salar)
}

\author{
Matthew Sprague ${ }^{1}$, Eldar Å. Bendiksen ${ }^{2}$, James R. Dick ${ }^{1}$, Fiona Strachan ${ }^{1}$, Jarunan Pratoomyot ${ }^{1}$, \\ Marc H. G. Berntssen ${ }^{3}$, Douglas R. Tocher ${ }^{1}$ and John Gordon Bell ${ }^{1 *}$ \\ ${ }^{1}$ Institute of Aquaculture, University of Stirling, Stirling FK9 4LA, UK \\ ${ }^{2}$ BioMar AS, Nordre Gate 11, N-7484 Trondheim, Norway \\ ${ }^{3}$ National Institute of Nutrition and Seafood Research, N-5817 Bergen, Norway
}

(Received 16 June 2009 - Revised 2 December 2009 - Accepted 4 December 2009 - First published online 1 March 2010)

\begin{abstract}
The health benefits of seafood are well documented and based on the unique supply of $n$ - 3 highly unsaturated fatty acids (HUFA). Aquaculture now contributes about $50 \%$ of food-grade seafood globally and Atlantic salmon (Salmo salar) is a rich source of $n$-3 HUFA. However, salmon and other oily fish can accumulate lipophilic persistent organic pollutants (POP), including dioxins (PCDD/F), polychlorinated biphenyls (PCB) and polybrominated diphenyl ethers (PBDE), derived largely from feed. In the present study, triplicate groups of salmon, of initial weight $0.78 \mathrm{~kg}$, were fed one of three experimental diets for 11 weeks. The diets were coated with either a northern fish oil (FO) with a high POP content (cNFO), the same oil that had been decontaminated (deNFO) or a blend of southern fish oil, rapeseed and soyabean oils (SFO/RO/SO). Dietary PCDD/F + dioxin-like PCB (DL-PCB) concentrations were 17.36, 0.45 and $0.53 \mathrm{ng}$ toxic equivalents (TEQ)/kg, respectively. After 11 weeks, the flesh concentrations in fish fed the cNFO, deNFO and SFO/RO/SO diets were 6.42, $0 \cdot 34$ and $0.41 \mathrm{ng}$ TEQ/kg, respectively. There were no differences in flesh EPA and DHA between fish fed the cNFO or deNFO diets although EPA and DHA were reduced by 50 and $30 \%$, respectively, in fish fed the $\mathrm{SFO} / \mathrm{RO} / \mathrm{SO}$ diet. Thus, decontaminated FO can be used to produce salmon high in $n-3$ HUFA and low in POP. Salmon produced using deNFO would be of high nutritional value and very low in POP and would utilise valuable fish oils that would otherwise be destroyed due to their high pollutant concentrations.
\end{abstract}

Fatty acid composition: Atlantic salmon: Dioxins: Polychlorinated biphenyls: Decontaminated fish oil

In the 1970s, studies on Greenland Inuit populations established that, despite consuming high-lipid diets, cardiac disease was virtually absent in these populations and that this was due to their high fish intake ${ }^{(1)}$. Subsequently, the beneficial effects of $n-3$ highly unsaturated fatty acids (HUFA), especially EPA $(20: 5 n-3)$ and DHA $(22: 6 n-3)$, have been shown to have cardioprotective activity ${ }^{(2,3)}$. More recently, the benefits of increased EPA and DHA intake have been shown for a wide range of lifestyle disorders with an associated inflammatory pathology ${ }^{(4,5)}$ as well as improving the symptoms of certain neurological disorders ${ }^{(6)}$. Due to the proven benefits of $n-3$ HUFA, numerous governmental and non-governmental organisations across the world currently advise increased fish intake as a means of improving the health of their citizens ${ }^{(7,8)}$.

Atlantic salmon (Salmo salar) can store large quantities of oil in their flesh and this makes them a rich source of $n-3$
$\operatorname{HUFA}^{(9,10)}$. However, the oil-rich flesh can also accumulate lipophilic undesirable compounds, including polychlorinated dibenzo- $p$-dioxins (PCDD) and polychlorinated dibenzofurans (PCDF) (collectively known as dioxins or PCDD/F), dioxinlike non-ortho and mono-ortho polychlorinated biphenyls (PCB), known collectively as dioxin-like (DL) PCB and polybrominated diphenyl ethers (PBDE), among others ${ }^{(11-15)}$. For these reasons there is currently considerable interest to investigate the transfer of persistent organic pollutants (POP) from feed to farmed fish as well as assessing the potential for transfer to humans and any consequences for human health ${ }^{(16,17)}$.

There are 210 dioxin (seventy-five PCDD and 135 PCDF congeners) and 209 PCB congeners, of which seventeen PCDD/PCDF congeners and twelve DL-PCB have been assigned toxic equivalency factors (TEF) by the WHO, according to their relative toxicity to $2,3,7,8$ tetra chlorinated dibenzo dioxin (TCDD). The concentration of PCDD/F and

\footnotetext{
Abbreviations: ASE ${ }^{\mathrm{TM}}$, accelerated solvent extractor; cNFO, control northern fish oil; deNFO, decontaminated northern fish oil; DL, dioxin-like; EU, European Union; FO, fish oil; FSA, Food Standards Agency; HUFA, highly unsaturated fatty acid; PBDE, polybrominated diphenyl ether; PCB, polychlorinated biphenyl; PCDD, polychlorinated dibenzo-p-dioxin; PCDD/F, dioxins; PCDF, polychlorinated dibenzofuran; POP, persistent organic pollutant; QC, qualitycontrol; SFO/RO/SO, southern fish oil; rapeseed oil, soyabean oil; TEF, toxic equivalency factor; TEQ, toxic equivalent; VO, vegetable oil.

* Corresponding author: Professor John Gordon Bell, fax +44 1786 472133, email g.j.bell@stir.ac.uk
} 
DL-PCB is expressed as toxic equivalents (TEQ), where a TEF is applied to the concentration of the individual congeners and summed to generate the total TEQ in a mixture of the twenty-nine PCDD/F and DL-PCB congeners. The TEF established in 1997 by the WHO have been most widely used for human risk assessment by government bodies ${ }^{(18)}$; these TEF were re-evaluated in $2005^{(19)}$. Application of these factors to individual PCDD/F and DL-PCB congener concentrations in a feed or fish can be used to determine the level of TEQ present. PCDD/F and PCB have originated either by natural means, such as forest fires and incomplete combustion (dioxins), or by industrial activity (PCDD/F and PCB) and both have half-lives of several decades and are highly persistent in the marine biota ${ }^{(20)}$.

In addition to $\mathrm{PCDD} / \mathrm{F}$ and $\mathrm{PCB}$, the $\mathrm{PBDE}$ are of more recent origin, having been introduced as flame retardants in household furnishings, computers and electrical circuits since the $1970 \mathrm{~s}^{(12)}$. As with PCDD/F and PCB, PBDE are lipophilic and accumulate in the aquatic biota and humans $^{(12,21)}$ although at the present time no TEQ have been assigned for any PBDE congeners. Although there are 209 possible PBDE congeners, only a few are present in commercial mixtures and those are represented in tissues by seven principal congeners, namely PBDE 28, 47, 99, 100, 153, 154 and $183^{(21)}$.

Within the European Union (EU), limit values for PCDD/F were established in 2001, which were revised in 2006 to include concentrations of all twenty-nine PCDD/F and DL-PCB congeners assigned WHO $\mathrm{TEF}^{(22,23)}$. These limit values cover raw materials, feeds and fish products. The current EU limit values are 24, 4.5, 7 and $8 \mathrm{ng} \mathrm{TEQ} / \mathrm{kg}$, for fish oil (FO), fish meal, fish feed and fish products, respectively. The main contributor to POP in fish feeds and fish is FO derived from pelagic marine fish ${ }^{(24)}$. In recent years a number of studies have been conducted where FO was replaced by terrestrial vegetable oils (VO) in salmon feeds ${ }^{(9,10,14,15)}$. The fish produced using diets with a high VO content contained significantly lower levels of POP compared with fish grown on diets with a high marine FO content ${ }^{(14,25)}$. However, the reduction in POP was accompanied by reductions in EPA and DHA of 50-65\%, which would obviously reduce the health benefits of this product to the consumer $^{(14,15)}$. With the introduction of the revised EU limits for PCDD/F and DL-PCB in 2006, some of the FO previously used in aquafeeds would no longer comply with these new limits and so would have to be removed from the food chain. The loss of valuable $n-3$ HUFA in this way, at a time when FO have reached their sustainable production limits and prices are rising rapidly, is a major dilemma and has increased the desire to develop technology to clean FO of POP so that they might be used in aquafeeds ${ }^{(26,27)}$.

The aim of the present study was to investigate the effects on tissue POP concentrations of replacing northern FO, containing high levels of POP, with either the same oil which had been cleaned using a decontamination protocol or a blend of southern FO, soya and rapeseed oils (4:3:3, by vol.). The three diets were fed to triplicate groups of Atlantic salmon in sea cages for a period of 11 weeks. The effects of these three treatments on PCDD/F, DL-PCB, PBDE and n-3 HUFA concentrations in fish feed and flesh are presented.

\section{Materials and methods}

Fish, husbandry and diets

Three $9 \mathrm{~mm}$ extruded diets were prepared with the same basal composition, but were top coated with three different oils and were prepared at the BioMar Tech Centre, Brande, Denmark (Table 1). The diets were formulated to satisfy the nutritional requirements of salmonid fish ${ }^{(28)}$, and contained $33 \%$ protein and $34 \%$ lipid. The three diets contained either (a) $100 \%$ northern FO (cNFO) as control, (b) $100 \%$ decontaminated northern FO (deNFO), or (c) a blend of southern FO and rapeseed and soya oil in a ratio of 40:30:30 (SFO/RO/SO). The deNFO was the same product and batch as the cNFO following the decontamination process. The cNFO was selected to contain high levels of POP and this oil was subjected to a two-stage decontamination process (FF Skagen, Skagen, Denmark) that involved an initial adsorption using activated carbon that was designed to remove about $90 \%$ of the PCDD/F. The second step was a thin-film deodorisation step that should remove up to $95 \%$ of PCB as well as pesticides and other contaminants, NEFA and peroxides. The deNFO was representative of decontaminated oil currently commercially available in Europe. Atlantic salmon of initial mean weight $0.78 \pm 0.01 \mathrm{~kg}$ were fed one of the three experimental

Table 1. Diet formulations, proximate compositions $(\mathrm{g} / \mathrm{kg})$, energy $(\mathrm{kJ} / \mathrm{g})$ and major fatty acid compositions (\% total fatty acids) of the three experimental diets fed to Atlantic salmon (Salmo salar) for 11 weeks

\begin{tabular}{|c|c|c|c|}
\hline Diet... & cNFO & deNFO & SFO/RO/SO \\
\hline \multicolumn{4}{|l|}{ Component } \\
\hline Fish meals & 378 & 378 & 378 \\
\hline Legume meals & 149 & 149 & 149 \\
\hline Northern fish oil & 325 & - & - \\
\hline Decontaminated northern fish oil & - & 325 & - \\
\hline Southern fish oil & - & - & 130 \\
\hline Rapeseed oil & - & - & 98 \\
\hline Soyabean oil & - & - & 98 \\
\hline Binder & 140 & 140 & 140 \\
\hline Premixes & $9 \cdot 2$ & 9.2 & $9 \cdot 2$ \\
\hline \multicolumn{4}{|l|}{ Composition (g/kg) } \\
\hline Protein & 326 & 322 & 328 \\
\hline Oil & 336 & 343 & 342 \\
\hline Moisture & 60 & 55 & 55 \\
\hline Ash & 78 & 77 & 78 \\
\hline Fibre & 21 & 22 & 20 \\
\hline Digestible energy $(\mathrm{kJ} / \mathrm{g})$ & $25 \cdot 3$ & $25 \cdot 3$ & $25 \cdot 2$ \\
\hline \multicolumn{4}{|l|}{ Fatty acid } \\
\hline $16: 0$ & $19 \cdot 2$ & $18 \cdot 8$ & $13 \cdot 5$ \\
\hline Total saturates* & $27 \cdot 8$ & $29 \cdot 3$ & $23 \cdot 1$ \\
\hline $18: 1 n-9$ & $25 \cdot 9$ & $21 \cdot 6$ & 29.5 \\
\hline Total monounsaturates $\dagger$ & $42 \cdot 0$ & $40 \cdot 0$ & 36.5 \\
\hline $18: 2 n-6$ & $3 \cdot 8$ & $4 \cdot 3$ & $23 \cdot 1$ \\
\hline Total $n-6 \neq$ & $5 \cdot 6$ & $5 \cdot 9$ & 23.9 \\
\hline $18: 3 n-3$ & $2 \cdot 7$ & $2 \cdot 3$ & $5 \cdot 1$ \\
\hline $20: 5 n-3$ & $6 \cdot 7$ & $7 \cdot 2$ & $5 \cdot 2$ \\
\hline $22: 6 n-3$ & $11 \cdot 6$ & 11.4 & $4 \cdot 3$ \\
\hline Total $n-3 \S$ & $24 \cdot 7$ & $24 \cdot 7$ & $16 \cdot 5$ \\
\hline
\end{tabular}

cNFO, control northern fish oil; deNFO, decontaminated northern fish oil; SFO/ $\mathrm{RO} / \mathrm{SO}$, southern fish oil, rapeseed oil and soyabean oil.

* Includes $14: 0,15: 0,18: 0,20: 0$ and $22: 0$.

†Includes $16: 1 n-7,16: 1 n-9,20: 1 n-11,20: 1 n-7,18: 1 n-7,20: 1 n-9,22: 1 n-11$, $22: 1 n-9$ and $24: 1 n-9$.

$\ddagger$ Includes 18:3n-6, 20:2n-6, 20:3n-6, 20:4n-6, $22: 4 n-6$ and $22: 5 n-6$.

$\S$ Includes $18: 4 n-3,20: 4 n-3$ and $22: 5 n-3$. 
diets for 11 weeks in nine pens (each $5 \mathrm{~m}^{3}$ ) containing 120 fish/pen at the Fjord Research Station, Dønna, Norway. The experiment was conducted between July and October 2006 under ambient photoperiod and the mean seawater temperature was $11.5 \pm 2.7^{\circ} \mathrm{C}$ and salinity $31.9 \pm 0.8$ parts per trillion. Feed was supplied manually to apparent satiation with waste feed collection provided by an uplift system. Experimental procedures complied with the Norwegian code of practice for the care and use of animals for scientific purposes and there are no aspects of this trial that would cause aggravated or unnecessary harm or stress to the fish involved.

\section{Sample collection}

Samples of the three feeds were collected at the start of the trial and wrapped in foil before placing in sealable polythene bags and storing at $-20^{\circ} \mathrm{C}$. Samples of fish were collected at the start and end of the trial with three fish per pen (nine per dietary treatment) anaesthetised by metacaine $(50 \mathrm{mg} / \mathrm{l})$ and then killed by a blow to the head. Samples of flesh from the Norwegian quality cut (NQC) region were collected, wrapped in foil and immediately frozen at $-20^{\circ} \mathrm{C}$ and transported to the laboratory where they were stored at $-70^{\circ} \mathrm{C}$ until analysed. The samples were selected from fish that were close to the average fish weight in each pen. The three NQC samples from each pen were then pooled, to provide three samples per treatment group. Before analysis, the pooled steaks were homogenised in a food processor after removal of skin and bones. Samples of these homogenates were used for POP and fatty acid analyses.

\section{Analysis of polychlorinated dibenzo-p-dioxins and polychlorinated dibenzofurans, dioxin-like polychlorinated biphenyls and polybrominated diphenyl ethers}

Homogenised samples of wet flesh (about $50 \mathrm{~g}$ ) were freezedried for minimum of $12 \mathrm{~h}$ before extraction. Samples of diet (about $10 \mathrm{~g}$ ) were weighed as above and ground in a coffee grinder before extraction. The entire flesh and diet samples were extracted using isohexane in an accelerated solvent extractor ( $\mathrm{ASE}^{\mathrm{TM}}$; Dionex, Camberley, Surrey, UK). Each sample was accurately weighed, mixed using Hydromatrix ${ }^{\mathrm{TM}}$ (Varian Inc., Palo Alto, CA, USA) before the addition of $1 \mathrm{ml}$ of a $2 \mathrm{ng} / \mathrm{ml}{ }^{13} \mathrm{C}$-labelled PCDD/F and PCB internal standard (EPA-1613-LCS; Wellington Laboratories, Guelph, Canada). Samples were extracted by $\mathrm{ASE}^{\mathrm{TM}}$ for $20 \mathrm{~min}$ for two cycles with isohexane under pressure $(1500 \mathrm{psi}$; $10342 \mathrm{kPa})$ and temperature $\left(125^{\circ} \mathrm{C}\right)$. Fat and organic matter were removed from the $120 \mathrm{ml} \mathrm{ASE}^{\mathrm{TM}}$ extract by sulfuric acid treatment. A quantity of $50 \mathrm{ml}$ of $95-97 \%$ sulfuric acid was added to the lipid extract in a separation funnel and left for $72 \mathrm{~h}$. The sulfuric acid was drained off and the organic phase washed with $50 \mathrm{ml}$ nanopure water (Millipore UK Ltd, Watford, Herts, UK) and left for $3 \mathrm{~h}$.

Clean-up of the extracted lipid samples was then performed using the automated multi-column Power-Prep ${ }^{\text {TM }}$ System (Fluid Management Systems, Waltham, MA, USA) using a series of disposable Teflon columns of multi-layered silica ( $4 \mathrm{~g}$ acidic, $2 \mathrm{~g}$ basic and $1.5 \mathrm{~g}$ neutral), basic alumina $(8 \mathrm{~g})$ and carbon ( $2 \mathrm{~g}$ ). For high-lipid samples, high-capacity silica columns ( $28 \mathrm{~g}$ acidic, $16 \mathrm{~g}$ basic and $6 \mathrm{~g}$ neutral) were used.
The total run time was $150 \mathrm{~min}$ followed by a 40 min preventative decontamination program. The mono-ortho PCB were collected in $120 \mathrm{ml}$ isohexane-dichloromethane $(1: 1, \mathrm{v} / \mathrm{v})$ and the PCDD/F and non-ortho PCB eluted in $120 \mathrm{ml}$ toluene. The purified fractions were evaporated to about $5 \mathrm{ml}$ by rotary evaporation (Rotavapor ${ }^{\circledR}$ R-200; Büchi Ltd, Oldham, UK) in a heated water-bath set at $25^{\circ} \mathrm{C}$ and $320 \mathrm{mbar}$ pressure for mono-ortho $\mathrm{PCB}$ and $40^{\circ} \mathrm{C}$ and $70 \mathrm{mbar}$ pressure for $\mathrm{PCDD} / \mathrm{F}$ and non-ortho $\mathrm{PCB}$. The mono-ortho $\mathrm{PCB}$ fraction was evaporated to dryness under $\mathrm{N}_{2}$ (N-Evap $^{\mathrm{TM}}$ 111; Organomation Associates Inc., Berlin, MA, USA) at room temperature before $5 \mathrm{ml}$ isohexane and $5 \mathrm{ml}$ concentrated sulfuric acid were added, vortex mixed, and centrifuged ( $5 \mathrm{~min} ; 478 \mathrm{~g}$ ). The organic phase was transferred to a clean conical tube and evaporated to approximately $1 \mathrm{ml}$ under $\mathrm{N}_{2}$ before the addition of $1 \mathrm{ml}$ isooctane and further evaporation to $500 \mu \mathrm{l}$. The sample was finally transferred to a conical GC vial containing $150 \mu \mathrm{l}$ nonane as the keeper and evaporated to $100 \mu \mathrm{l}$ before analysis by GC-MS/MS.

The PCDD/F and non-ortho PCB fraction was evaporated to $500 \mu \mathrm{l}$ under $\mathrm{N}_{2}$ and transferred to a conical GC vial containing $60 \mu \mathrm{l}$ nonane before further evaporation to $10 \mu \mathrm{l}$ where $400 \mu \mathrm{l}$ isohexane and $10 \mu \mathrm{l}$ recovery standard (EPA-1613-ISS for PCDD/F and 68A-IS for PCB; Wellington Laboratories, Guelph, Canada) were added and vortex mixed. Sulfuric acid $(35 \mu \mathrm{l})$ was added to the vial, vortex mixed and left for $1 \mathrm{~h}$ before centrifugation $(5 \mathrm{~min} ; 1328 \mathrm{~g}$ ). The organic phase was transferred to a clean conical GC autosampler vial containing $10 \mu \mathrm{l}$ nonane as the keeper and evaporated to $10 \mu \mathrm{l}$ or $50 \mu \mathrm{l}$ before analysis by $\mathrm{GC}-\mathrm{MS}$ for PCDD/F or non-ortho PCB analysis, respectively.

Analysis of the twenty-nine PCDD/F and DL-PCB congeners with WHO TEF was conducted using GC-MS/MS on a Trace GC 2000 coupled to a Polaris Q ion trap MS/MS (Thermo Finnegan, Hemel Hempstead, Herts, UK). The chromatographic separations were conducted on a Rxi- ${ }^{\circledR} \mathrm{ms}$ (5\% phenyl-95\% dimethyl polysiloxane) fused silica column (Thames Restek UK Ltd, Saunderton, Bucks, UK), $30 \mathrm{~m} \times 0.25 \mathrm{~mm}$ internal diameter $\times 0.25 \mathrm{~mm}$ film thickness, with $\mathrm{He}$ as the carrier gas at $0.8 \mathrm{ml} / \mathrm{min}$. The injector temperature was kept at $250^{\circ} \mathrm{C}$ and samples and standards were injected in the splitless mode. MS conditions were in the positive electron ionisation $(\mathrm{EI}+)$ mode using automatic gain control with electron energy of $70 \mathrm{eV}$ and emission current of $250 \mu \mathrm{A}$. The transfer line and ion source were kept at 305 and $250^{\circ} \mathrm{C}$, respectively. Xcalibar version 1.3 software (Xcalibar Software, Inc., Herndon, VA, USA) was used for data acquisition and processing of results. The limit of quantification (LOQ) was determined by using nine times the background level (three times the limit of detection; LOD) in the blanks of each congener. Procedural blanks were run for each batch of up to ten samples. Each batch of samples was analysed with one procedural blank, one external qualitycontrol (QC) sample and one internal QC sample. The external QC was cod liver oil (Food Analysis Performance Assessment Scheme ${ }^{\circledR}$; CSL, York, UK; T0623) and the internal QC was internally validated salmon flesh. Percentage recoveries were in the range $78-114 \%$. Quantification of each congener is based on the isotope dilution method of the United States Environmental Protection Agency (USEPA) methods 1613 and $1668^{(29,30)}$. The range of LOQ for whole fish samples 
were $0.03-0.18 \mathrm{pg} / \mathrm{g}$ wet weight for PCDD/Fs, $0.03-0.06 \mathrm{pg} / \mathrm{g}$ wet weight for non-ortho $\mathrm{PCB}$ and $0.03-0.06 \mathrm{pg} / \mathrm{g}$ wet weight for mono-ortho $\mathrm{PCB}$. The congeners analysed included the seventeen PCDD/Fs and twelve DL-PCB, for which the WHO has established TEF from $1997^{(18)}$ and recently re-evaluated $\mathrm{TEF}^{(19)}$ (Table 2).

\section{Analysis of polybrominated diphenyl ethers}

For PBDE analysis, $25 \mathrm{~g}$ homogenised wet flesh were freezedried as described above. The dried flesh sample or $10 \mathrm{~g}$ diet was ground by mortar and pestle or coffee grinder, respectively, and $2.5 \mathrm{~g}$ flesh or diet was extracted using the $\mathrm{ASE}^{\mathrm{TM}}$ extraction cell containing $19 \mathrm{~g}$ silica gel-sulfuric acid mixture $(1: 1, w / w)$ and hydromatrix before addition of $20 \mu \mathrm{l}$ of a $500 \mathrm{ng} / \mathrm{ml}$ PBDE-119 internal standard (Wellington Laboratories, Guelph, Canada). Samples were extracted by $\mathrm{ASE}^{\mathrm{TM}}$ for $20 \mathrm{~min} \times$ two cycles with dichloromethane-isohexane $(4: 1, \mathrm{v} / \mathrm{v})$ under pressure $(1500 \mathrm{psi} ; 10342 \mathrm{kPa})$ and temperature $\left(40^{\circ} \mathrm{C}\right)$. The extract from the $\mathrm{ASE}^{\mathrm{TM}}$ was reduced to about $5 \mathrm{ml}$ by rotary evaporation at $30^{\circ} \mathrm{C}$ and $320 \mathrm{mbar}$ and

Table 2. Dietary concentrations (ng toxic equivalents/kg wet weight) of dioxin and dioxin-like polychlorinated biphenyl (PCB) congeners in the control northern fish oil (cNFO), decontaminated northern fish oil (deNFO) and southern fish oil, rapeseed oil and soyabean oil (SFO/ $\mathrm{RO} / \mathrm{SO})$ diets

\begin{tabular}{|c|c|c|c|}
\hline \multirow[b]{2}{*}{ Congener } & \multicolumn{3}{|c|}{ Diet } \\
\hline & cNFO & deNFO & SFO/RO/SO \\
\hline 1234678-HpCDD & 0.005 & 0.001 & 0.001 \\
\hline 123478-HxCDD & 0.028 & 0.009 & 0.007 \\
\hline 123678-HxCDD & 0.113 & 0.013 & 0.012 \\
\hline $12378-P e C D D$ & 1.386 & 0.081 & 0.038 \\
\hline 123789-HxCDD & 0.028 & 0.007 & 0.010 \\
\hline 2378-TCDD & 0.609 & 0.040 & 0.082 \\
\hline Sum of PCDD & $2 \cdot 169$ & 0.153 & 0.151 \\
\hline 1234678-HpCDF & 0.002 & nd & nd \\
\hline 123478-HxCDF & 0.084 & 0.013 & 0.005 \\
\hline 1234789-HxCDF & 0.001 & nd & 0.001 \\
\hline 123678-HxCDF & 0.102 & 0.006 & 0.005 \\
\hline 12378-PeCDF & 0.147 & 0.006 & 0.002 \\
\hline 123789-HxCDF & 0.018 & 0.012 & 0.009 \\
\hline 234678-HxCDF & 0.125 & 0.008 & 0.008 \\
\hline $23478-P e C D F$ & $4 \cdot 775$ & 0.058 & 0.050 \\
\hline 2378-TCDF & $1 \cdot 223$ & 0.011 & 0.015 \\
\hline Sum of PCDF & $6 \cdot 477$ & 0.114 & 0.094 \\
\hline PCB 105 & 0.355 & 0.004 & 0.007 \\
\hline PCB 114 & 0.081 & 0.002 & 0.001 \\
\hline PCB 118 & 1.043 & 0.010 & 0.014 \\
\hline PCB 123 & 0.010 & 0.001 & nd \\
\hline PCB 156 & 0.612 & 0.029 & 0.012 \\
\hline PCB 157 & 0.153 & 0.008 & 0.002 \\
\hline PCB 167 & 0.005 & nd & nd \\
\hline PCB 189 & 0.010 & 0.003 & nd \\
\hline Sum of mono-ortho PCB & $2 \cdot 269$ & 0.057 & 0.036 \\
\hline PCB 77 & 0.001 & 0.001 & 0.001 \\
\hline PCB 81 & 0.020 & nd & nd \\
\hline PCB 126 & $6 \cdot 4$ & 0.12 & 0.25 \\
\hline PCB 169 & 0.070 & 0.007 & 0.003 \\
\hline Sum of non-ortho PCB & $6 \cdot 4$ & 0.12 & 0.25 \\
\hline Sum of dioxins + PCB & $17 \cdot 4$ & 0.45 & 0.53 \\
\hline
\end{tabular}

TCDD, 2,3,7,8 tetra chlorinated dibenzo dioxin; PCDD, polychlorinated dibenzo-pdioxins; nd, not detected; TCDF, 2,3,7,8 tetra chlorinated dibenzofuran; PCDF, polychlorinated dibenzofurans. then reduced to $1 \mathrm{ml}$ under $\mathrm{N}_{2}$ at room temperature. Isohexane $(5 \mathrm{ml})$ and concentrated sulfuric acid $(2 \mathrm{ml})$ were added, vortex mixed and centrifuged (15 min at $1328 \mathrm{~g}$ ). The organic phase was transferred to a clean tube and the procedure repeated. The combined organic phases were reduced to $1 \mathrm{ml}$ under $\mathrm{N}_{2}$ and $100 \mu \mathrm{l}$ concentrated sulfuric acid added, mixed and centrifuged (4 min at $212 \mathrm{~g}$ ). The isohexane layer was then transferred to a silanised GC autosampler vial containing $500 \mu \mathrm{l}$ nonane as the keeper and the solvent evaporated under $\mathrm{N}_{2}$ to the nonane mark before analysis by $\mathrm{GC}-\mathrm{MS}$.

Analysis of the seven PBDE congeners (28, 47, 99, 100, 153, 154 and 183) was conducted using a Thermo Finnegan Trace GC Ultra equipped with a ZB5-MS column $(30 \mathrm{~m} \times 0.25 \mathrm{~mm}$ internal diameter $\times 0.25 \mu \mathrm{m}$ phase; Phenomenex, Macclesfield, Cheshire, UK) using He as the carrier gas coupled to a Trace DSQ MS (Bremen, Germany) in the negative chemical ion $(\mathrm{CI}-)$ mode and methane as the reagent gas at a flow rate of $2.0 \mathrm{ml} / \mathrm{min}$. The mass spectrometer was operated in the selective ion monitoring mode at $\mathrm{m} / \mathrm{z} .79$ and 81. Procedural blanks were the same as described for PCDD/F + DL-PCB above. The external QC was supplied by the Norwegian Institute of Public Health and the internal QC was internally validated salmon flesh. Xcalibar version 1.4 software (Xcalibar Software, Inc., Herndon, VA, USA) was used for data acquisition and processing of results. The range of limits of quantification (LOQ) for whole fish samples was $2-63 \mathrm{pg} / \mathrm{g}$ wet weight for PBDE.

\section{Lipid content and fatty acid compositions}

Total lipid was extracted from $1 \mathrm{~g}$ diet or flesh homogenates by homogenising in 20 volumes of ice-cold chloroformmethanol (2:1, v/v) using an Ultra-Turrax tissue disrupter (Fisher Scientific, Loughborough, Leics, UK). The total lipid fraction was prepared according to the method of Folch et al. ${ }^{(31)}$ with non-lipid impurities removed by washing with $0.88 \%(\mathrm{w} / \mathrm{v}) \mathrm{KCl}$. The lipid weight was determined gravimetrically after evaporation of solvent under $\mathrm{N}_{2}$ and desiccation in vacuo for at least $16 \mathrm{~h}$.

Fatty acid methyl esters (FAME) were prepared from diet and flesh total lipid by acid-catalysed transesterification according to the method of Christie ${ }^{(32)}$. Extraction and purification of FAME were performed as described by Tocher \& Harvie ${ }^{(33)}$. FAME were separated and quantified by GC (Carlo Erba Vega 8160; Milan, Italy) using a $30 \mathrm{~m} \times 0.32 \mathrm{~mm}$ internal diameter $\times 0.25 \mathrm{~mm}$ film thickness capillary column (CP Wax 52CB; Chrompak, London, UK) and cold on-column injection. $\mathrm{H}_{2}$ was used as the carrier gas and temperature programming was from $50^{\circ} \mathrm{C}$ to $150^{\circ} \mathrm{C}$ at $40^{\circ} \mathrm{C}$ per min and then to $230^{\circ} \mathrm{C}$ at $2 \cdot 0^{\circ} \mathrm{C}$ per min. Individual methyl esters were identified by comparison with known standards and by reference to published data ${ }^{(33,34)}$. Data were collected and processed using the Chromcard for Windows (version 2.01) computer package (Thermoquest Italia S.p.A., Milan, Italy).

\section{Statistical analysis}

Significance of differences $(P<0.05)$ between dietary treatments was determined by one-way ANOVA. Differences 
Table 3. Dietary concentrations ( $\mathrm{ng} / \mathrm{g}$ wet weight) of seven polybrominated diphenyl ether (PBDE) congeners in the control northern fish oil (cNFO), decontaminated northern fish oil (deNFO) and southern fish oil, rapeseed oil and soyabean oil (SFO/RO/SO) diets

\begin{tabular}{lccc}
\hline Diet... & cNFO & deNFO & SFO/RO/SO \\
\hline PBDE 28 & 0.22 & 0.013 & nd \\
PBDE 47 & 3.6 & 0.87 & 0.23 \\
PBDE 99 & 0.84 & 0.34 & 0.027 \\
PBDE 100 & 0.89 & 0.45 & 0.059 \\
PBDE 153 & 0.27 & 0.17 & nd \\
PBDE 154 & 0.15 & 0.095 & nd \\
PBDE 183 & nd & nd & nd \\
Sum of seven PBDE & 5.94 & 1.90 & 0.31 \\
\hline
\end{tabular}

nd, Not detected.

between means were determined by Tukey's test. Data identified as non-homogeneous, using Bartlett's test, were subjected to log or arcsin transformation before applying the ANOVA. ANOVA was performed using a GraphPad Prism (version 4.0) statistical package (GraphPad Software, San Diego, CA, USA).

\section{Results}

The fish grew from an initial weight of $0.78 \mathrm{~kg}$ to $2.19 \mathrm{~kg}$ over the 11-week trial and there were no significant differences in final weights between the three treatments. Specific growth rate $(\% / d)$ values were in the range $1.34-1.35$ and thermal growth coefficient (TGC) between 3.86 and 3.92 while the feed conversion ratio values were in the range 0.96-0.98. There were no differences between treatments and all these values were comparable with normal commercial practice for salmon of this size and culture conditions.

The cNFO diet contained $17.4 \mathrm{ng}$ TEQ $/ \mathrm{kg}$ of the twentynine WHO PCDD/F and DL-PCB congeners with assigned TEF (Table 2). This value is significantly higher than the EU limit for fish feeds of $7 \mathrm{ng} T E Q / \mathrm{kg}^{(22)}$. However, following the two-step decontamination of the $\mathrm{cNFO}$, this value was reduced to $0.45 \mathrm{ng} \mathrm{TEQ} / \mathrm{kg}$ in the deNFO diet that was comparable with the value of $0.53 \mathrm{ng} \mathrm{TEQ} / \mathrm{kg}$ in the SFO/RO/ SO blend diet (Table 2). These values represent 6.3 and $7.6 \%$ of the EU limit, respectively ${ }^{(22)}$, and indicate that the decontamination process was successful. When comparing the POP concentrations in the three diets, a reduction of $\mathrm{PCDD} / \mathrm{F}$ of $97 \%$ was observed for both the deNFO and

Table 4. Flesh concentrations (ng toxic equivalents/kg wet weight) of dioxin and dioxin-like polychlorinated biphenyl (PCB) congeners in salmon (Salmo salar) at the start of the trial and after feeding the control northern fish oil (cNFO), decontaminated northern fish oil (deNFO) and southern fish oil, rapeseed oil and soyabean oil (SFO/RO/SO) diets for 11 weeks

(Mean values ( $n$ 3) and standard deviations)

\begin{tabular}{|c|c|c|c|c|c|c|c|c|}
\hline \multirow{2}{*}{$\begin{array}{l}\text { Diet... } \\
\text { Congener }\end{array}$} & \multicolumn{2}{|c|}{ Initial } & \multicolumn{2}{|c|}{ cNFO } & \multicolumn{2}{|l|}{ deNFO } & \multicolumn{2}{|c|}{ SFO/RO/SO } \\
\hline & Mean & SD & Mean & SD & Mean & SD & Mean & SD \\
\hline 1234678-HpCDD & nd & & nd & & nd & & nd & \\
\hline 123478-HxCDD & 0.002 & 0.001 & 0.004 & 0.002 & 0.002 & 0.001 & 0.002 & 0.001 \\
\hline 123678-HxCDD & 0.003 & 0.002 & 0.008 & 0.004 & 0.002 & 0.001 & 0.002 & 0.001 \\
\hline 12378-PeCDD & $0.034^{a, b}$ & 0.009 & $0.363^{a}$ & 0.091 & $0.013^{b}$ & 0.004 & $0.030^{\mathrm{b}}$ & 0.009 \\
\hline 123789-HxCDD & 0.002 & 0.001 & 0.004 & 0.002 & 0.003 & 0.002 & 0.004 & 0.002 \\
\hline 2378-TCDD & $0.023^{b}$ & 0.009 & $0.191^{\mathrm{a}}$ & 0.016 & $0.013^{b}$ & 0.004 & $0.015^{b}$ & 0.007 \\
\hline Sum of PCDD & $0.065^{b}$ & 0.021 & $0.570^{\mathrm{a}}$ & 0.086 & $0.030^{\mathrm{b}}$ & 0.014 & $0.053^{b}$ & 0.018 \\
\hline 1234678-HpCDF & nd & & nd & & nd & & nd & \\
\hline 123478-HxCDF & $0.001^{\mathrm{b}}$ & 0.000 & $0.006^{a}$ & 0.003 & $0.001^{b}$ & 0.000 & $0.002^{\mathrm{b}}$ & 0.001 \\
\hline 1234789-HxCDF & nd & & nd & & nd & & nd & \\
\hline 123678-HxCDF & 0.001 & 0.000 & 0.006 & 0.005 & 0.001 & 0.000 & 0.002 & 0.001 \\
\hline 12378-PeCDF & $0.003^{b}$ & 0.001 & $0.025^{a}$ & 0.013 & $0.002^{b}$ & 0.001 & $0.002^{b}$ & 0.001 \\
\hline 123789-HxCDF & 0.002 & 0.001 & 0.003 & 0.002 & 0.001 & 0.000 & 0.002 & 0.001 \\
\hline 234678-HxCDF & $0.002^{b}$ & 0.001 & $0.010^{a}$ & 0.003 & $0.001^{b}$ & 0.000 & $0.001^{b}$ & 0.000 \\
\hline 23478-PeCDF & $0.053^{b}$ & 0.014 & $1 \cdot 017^{a}$ & 0.267 & $0.018^{b}$ & 0.001 & $0.026^{b}$ & 0.008 \\
\hline 2378-TCDF & $0.060^{\mathrm{b}}$ & 0.018 & $0.420^{\mathrm{a}}$ & 0.016 & $0.011^{c}$ & 0.003 & $0.013^{\mathrm{C}}$ & 0.001 \\
\hline Sum of PCDF & $0.121^{b}$ & 0.027 & $1.483^{\mathrm{a}}$ & 0.315 & $0.035^{\mathrm{b}}$ & 0.006 & $0.046^{b}$ & 0.012 \\
\hline PCB 105 & $0.035^{\mathrm{b}}$ & 0.022 & $0.214^{a}$ & 0.033 & $0.015^{\mathrm{b}}$ & 0.005 & $0.013^{b}$ & 0.002 \\
\hline PCB 114 & $0.007^{\mathrm{b}}$ & 0.003 & $0.046^{a}$ & 0.007 & $0.003^{b}$ & 0.001 & $0.002^{b}$ & 0.001 \\
\hline PCB 118 & $0.079^{b}$ & 0.034 & $0.471^{a}$ & 0.040 & $0.033^{b}$ & 0.011 & $0.028^{b}$ & 0.002 \\
\hline PCB 123 & $0.001^{b}$ & 0.000 & $0.008^{a}$ & 0.001 & nd & & $0.001^{\mathrm{b}}$ & 0.001 \\
\hline PCB 156 & $0.047^{b}$ & 0.020 & $0.355^{\mathrm{a}}$ & 0.035 & $0.031^{b}$ & 0.007 & $0.017^{b}$ & 0.002 \\
\hline PCB 157 & $0.014^{b}$ & 0.008 & $0.091^{a}$ & 0.010 & $0.011^{b}$ & 0.004 & $0.004^{b}$ & 0.001 \\
\hline PCB 167 & nd & & $0.004^{a}$ & 0.001 & nd & & nd & \\
\hline PCB 189 & $0.001^{b}$ & 0.000 & $0.006^{a}$ & 0.001 & $0.002^{b}$ & 0.001 & nd & \\
\hline Sum of mono-ortho PCB & $0.184^{\mathrm{b}}$ & 0.086 & $1 \cdot 195^{a}$ & $0 \cdot 106$ & $0.096^{b}$ & 0.027 & $0.066^{b}$ & 0.005 \\
\hline PCB 77 & $0.001^{b}$ & 0.001 & $0.014^{\mathrm{a}}$ & 0.002 & nd & & $0.002^{b}$ & 0.001 \\
\hline PCB 81 & nd & & 0.001 & 0.000 & 0.001 & 0.001 & 0.001 & 0.000 \\
\hline PCB 126 & $0.718^{b}$ & 0.164 & $3 \cdot 159^{a}$ & 0.177 & $0.195^{c}$ & 0.023 & $0.240^{c}$ & 0.045 \\
\hline PCB 169 & $0.008^{b}$ & 0.005 & $0.056^{a}$ & 0.009 & $0.002^{b}$ & 0.002 & $0.003^{\mathrm{b}}$ & 0.001 \\
\hline Sum of non-ortho PCB & $0.726^{b}$ & 0.166 & $3 \cdot 213^{a}$ & 0.187 & $0.202^{\mathrm{C}}$ & 0.022 & $0.241^{c}$ & 0.042 \\
\hline Sum of dioxins + PCB & $1.061^{b}$ & 0.154 & $6 \cdot 421^{a}$ & 0.397 & $0.339^{c}$ & 0.044 & $0.406^{c}$ & 0.032 \\
\hline
\end{tabular}

TCDD, 2,3,7,8 tetra chlorinated dibenzo dioxin; PCDD, polychlorinated dibenzo-p-dioxins; nd, not detected; TCDF, 2,3,7,8 tetra chlorinated dibenzofuran; PCDF, polychlorinated dibenzofurans.

a,b,c Mean values within a row with unlike superscript letters were significantly different $(P<0.05)$. 
Table 5. Flesh concentrations (ng/g wet weight) in salmon (Salmo salar) of seven polybrominated diphenyl ether (PBDE) congeners at the start of the trial and after feeding the control northern fish oil (cNFO), decontaminated northern fish oil (deNFO) or southern fish oil, rapeseed oil and soyabean oil (SFO/RO/SO) diets for 11 weeks

(Mean values ( $n$ 3) and standard deviations)

\begin{tabular}{|c|c|c|c|c|c|c|c|c|}
\hline \multirow{2}{*}{ Diet... } & \multicolumn{2}{|c|}{ Initial } & \multicolumn{2}{|c|}{ cNFO } & \multicolumn{2}{|c|}{ deNFO } & \multicolumn{2}{|c|}{ SFO/RO/SO } \\
\hline & Mean & SD & Mean & SD & Mean & SD & Mean & SD \\
\hline PBDE 28 & $0.009^{b}$ & 0.000 & $0.042^{a}$ & 0.001 & $0.003^{c}$ & 0.001 & $0.003^{c}$ & 0.001 \\
\hline PBDE 47 & $0.178^{\mathrm{b}}$ & 0.01 & $0.59^{\mathrm{a}}$ & 0.01 & $0 \cdot 12^{\mathrm{c}}$ & 0.01 & $0.06^{\mathrm{d}}$ & 0.02 \\
\hline PBDE 99 & $0.034^{c}$ & 0.006 & $0 \cdot 16^{\mathrm{a}}$ & 0.01 & $0.062^{b}$ & 0.000 & $0.018^{\mathrm{c}}$ & 0.007 \\
\hline PBDE 100 & $0.027^{\mathrm{b}}$ & 0.001 & $0.092^{\mathrm{a}}$ & 0.010 & $0.038^{\mathrm{b}}$ & 0.001 & $0.010^{c}$ & 0.002 \\
\hline PBDE 153 & $0.006^{c}$ & 0.000 & $0.028^{a}$ & 0.002 & $0.013^{b}$ & 0.001 & $0.002^{\mathrm{d}}$ & 0.000 \\
\hline PBDE 154 & $0.009^{c}$ & 0.002 & $0.028^{\mathrm{a}}$ & 0.001 & $0.019^{b}$ & 0.001 & $0.002^{\mathrm{d}}$ & 0.000 \\
\hline PBDE 183 & nd & & nd & & nd & & nd & \\
\hline Sum of PBDE & $0.26^{\mathrm{b}}$ & 0.01 & $0.94^{\mathrm{a}}$ & 0.002 & $0.25^{\mathrm{b}}$ & 0.02 & $0.095^{\mathrm{c}}$ & 0.033 \\
\hline
\end{tabular}

nd, Not detected.

a,b,c,d Mean values within a row with unlike superscript letters were significantly different $(P<0.05)$.

SFO/RO/SO diets compared with the cNFO diet. Similarly, an overall $98 \%$ reduction of both mono-ortho and non-ortho PCB was noted compared with the cNFO diet, with individual congeners being reduced by $71-99$ and $93-99 \%$, respectively (Table 2).

The sum concentrations of the seven PBDE congeners in diets were $5.9,1.9$ and $0.31 \mathrm{ng} / \mathrm{g}$ wet weight, for the cNFO, deNFO and SFO/RO/SO diets, respectively (Table 3). The sum of PBDE was reduced by $68 \%$ for the deNFO compared with the cNFO diet, and $95 \%$ for the SFO/RO/SO, compared with the $\mathrm{cNFO}$ diet. The individual PBDE congeners were reduced by $35-94 \%$ in the deNFO diet and by $93-100 \%$ in the SFO/RO/SO diet compared with the cNFO diet (Table 3).

In the initial fish at the start of the trial, the sum of flesh $\mathrm{PCDD} / \mathrm{F}+\mathrm{DL}-\mathrm{PCB}$ was $1.06 \mathrm{ng} \mathrm{TEQ} / \mathrm{kg}$ (Table 4). In fish fed the cNFO diet for 11 weeks this value increased significantly to $6.42 \mathrm{ng} \mathrm{TEQ} / \mathrm{kg}$ while in fish fed the deNFO and $\mathrm{SFO} / \mathrm{RO} / \mathrm{SO}$ diets the concentrations were significantly reduced to 0.34 and $0.41 \mathrm{ng} \mathrm{TEQ} / \mathrm{kg}$, respectively, compared with the initial fish (Table 4). The flesh concentration for the fish fed cNFO was, however, below the EU limit value of $8 \mathrm{ng} \mathrm{TEQ} / \mathrm{kg}$ while the deNFO and SFO/RO/SO flesh represented $4 \cdot 3$ and $5 \cdot 1 \%$ of the EU limit value, respectively ${ }^{(23)}$.

In the initial fish flesh at the start of the trial, the sum concentration of the seven PBDE congeners was $0.26 \mathrm{ng} / \mathrm{g}$ wet weight. After feeding the experimental diets for 11 weeks the flesh value in fish fed the cNFO diet increased significantly to $0.94 \mathrm{ng} / \mathrm{g}$, while fish fed the deNFO diet had similar levels to the initial fish of $0.25 \mathrm{ng} / \mathrm{g}$ and fish fed the SFO/RO/SO diet had a significantly reduced concentration of $0.095 \mathrm{ng} / \mathrm{g}$, compared with the initial flesh (Table 5). The sum of PBDE was reduced by $73 \%$ for the deNFO compared with the cNFO diet and by $90 \%$ for the SFO/RO/SO compared with the cNFO diet.

Flesh total lipid content increased from 9.0 (SD 0.9) \% in initial fish to 17.0 (SD 1.6) $\%$ in the final fish. There were no differences between treatments. Flesh fatty acid levels were closely correlated to dietary values and DHA values were similar for fish fed the cNFO and deNFO diets, although EPA was significantly higher in the latter (Fig. 1). By contrast, the DHA and EPA values in the flesh of fish fed the SFO/RO/ SO diet were significantly lower than in the two FO groups, being reduced by 50 and $30 \%$, respectively (Fig. 1). At the same time, fish fed the SFO/RO/SO diet had increased levels of linoleic $(18: 2 n-6)$ and linolenic acids $(18: 3 n-3)$ of 3.6- and 2-fold, respectively (Fig. 1).

Data from the present study show that consumption of two $140 \mathrm{~g}$ portions of $\mathrm{cNFO}$ salmon would represent $171 \%$ of the weekly limit for PCDD/F + DL-PCB for girls and women of reproductive age ${ }^{(35)}$ (UK Food Standards Agency (FSA); www.food.gov.uk) (Fig. 2). Portions of $140 \mathrm{~g}$ are the standardised portion sizes used by the FSA. However, this value assumes that salmon is the only dietary input of PCDD/F and DL-PCB while in practice the two $140 \mathrm{~g}$ portions would contribute to more than $171 \%$ of the weekly limit due to the consumption of other food products that also contain POP, albeit at a lower level than that seen in the cNFO salmon. In the UK, as in most countries in the developed world, the largest contribution to weekly POP intake is derived from dairy products ${ }^{(4)}$. Consuming four $140 \mathrm{~g}$ portions

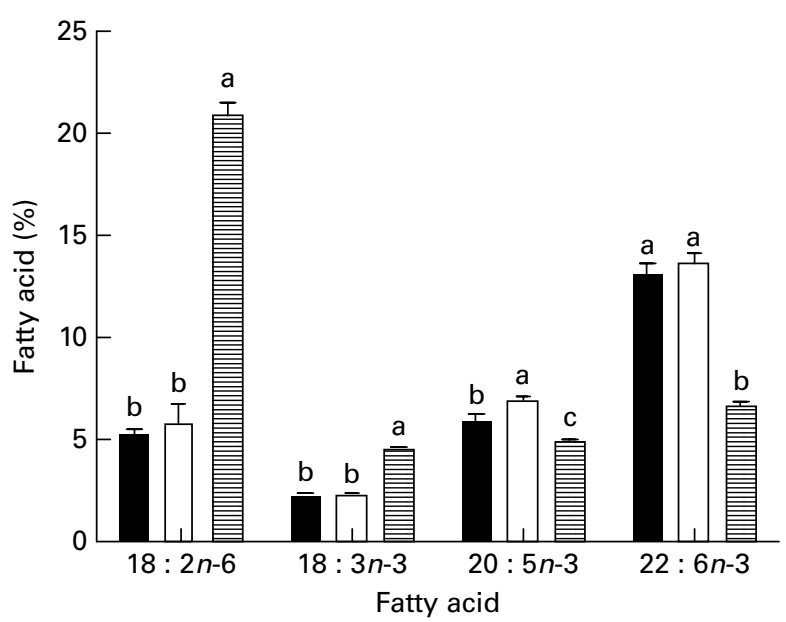

Fig. 1. Concentrations (\% total fatty acids) of $18: 2 n-6,18: 3 n-3,20: 5 n-3$ and $22: 6 n-3$ in the flesh of salmon (Salmo salar) fed either the northern fish oil $(\square)$, decontaminated northern fish oil $(\square)$ or southern fish oil, rapeseed and soyabean oil (目) diet for 11 weeks. Values are means, with standard deviations represented by vertical bars. ${ }^{a, b, c}$ Mean values with unlike letters were significantly different $(P<0.05)$. 


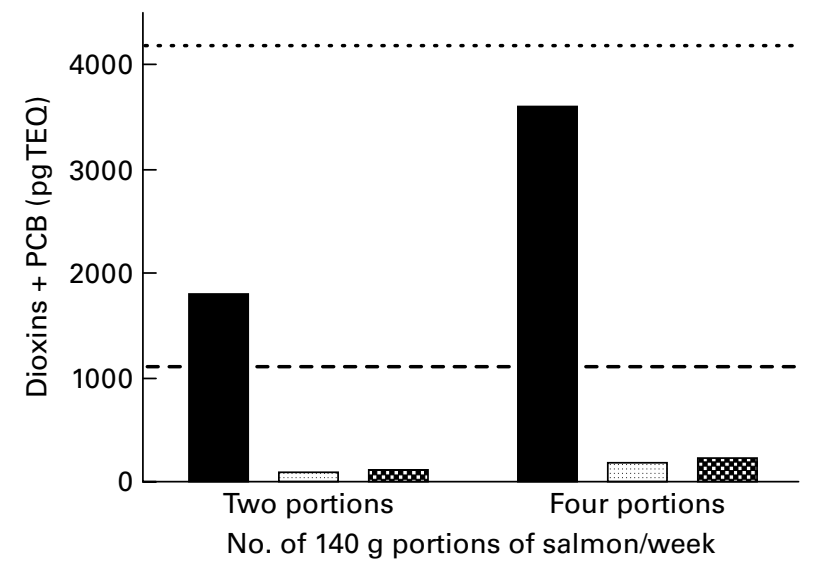

Fig. 2. Amount of dioxin + dioxin-like polychlorinated biphenyls $(P C B)$ present in two or four $140 \mathrm{~g}$ portions of salmon (Salmo salar), produced using

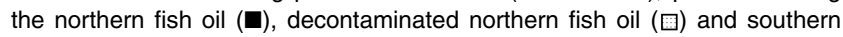
fish oil, rapeseed and soyabean oil (B) diets. (--), UK Food Standards Agency (FSA) maximum for dioxin + PCB intake of $56 \mathrm{pg} / \mathrm{kg}$ per week for a $75 \mathrm{~kg}$ individual; (- - -), UK FSA maximum intake of $14 \mathrm{pg} / \mathrm{kg}$ per week for a $75 \mathrm{~kg}$ girl or woman of reproductive age. TEQ, toxic equivalents.

would represent $86 \%$ of the FSA weekly limit value for boys, men and women over reproductive age. By comparison, consuming two $140 \mathrm{~g}$ portions of salmon fed the deNFO or SFO/ $\mathrm{RO} / \mathrm{SO}$ diets represents 9.0 and $10.8 \%$, respectively, of the weekly limit for girls and women of reproductive age, while consuming four $140 \mathrm{~g}$ portions represents 4.5 and $5.4 \%$, respectively, of the weekly limit for PCDD/F + DL-PCB for boys, men and women over reproductive age (Fig. 2). Over the years many advisories have been issued on guideline intakes for EPA and DHA in humans ${ }^{(4,7,8)}$. The intake advice of the International Society for the Study of Fatty Acids and Lipids (ISSFAL) is for a daily intake of $\mathrm{EPA}+\mathrm{DHA}$ of $500 \mathrm{mg}$ or $3.5 \mathrm{~g} /$ week $^{(8)}$. Thus, two $140 \mathrm{~g}$ portions of salmon fed the cNFO, deNFO and SFO/RO/SO diets provide $4 \cdot 81,5 \cdot 14$ and $2 \cdot 83 \mathrm{~g} \mathrm{EPA}+$ DHA, respectively, while four $140 \mathrm{~g}$ portions provide $9.62,10.29$ and $5.67 \mathrm{~g}$ EPA + DHA, respectively (Fig. 3).

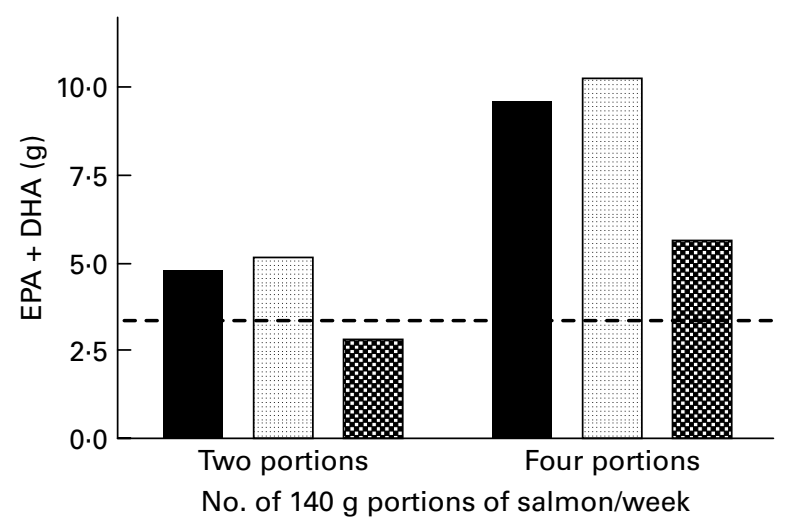

Fig. 3. Amount of EPA + DHA provided by two or four $140 \mathrm{~g}$ portions of salmon (Salmo salar), produced using the northern fish oil (ם), decontaminated northern fish oil (⿴囗十) and southern fish oil, rapeseed and soyabean oil ( $\mathbf{0}$ ) diets. (- - ), International Society for the Study of Fatty Acids and Lipids (ISSFAL) recommended EPA + DHA intake of $3.5 \mathrm{~g} / \mathrm{week}$.

\section{Discussion}

The cNFO diet used a sprat oil from the Baltic Sea that was selected to be high in POP; this same oil was subjected to the two-step decontamination process at FF Skagen (Skagen, Denmark) to produce the deNFO. Previously, removal of $>90 \%$ of PCDD/F from FO could be achieved using activated carbon treatment alone. However, removal of DL-PCB was less effective and required the use of high-temperature deodorisation that could cause oxidation of $\operatorname{HUFA}^{(26,36)}$. More effective removal of both $\mathrm{PCDD} / \mathrm{F}$ and DL-PCB can be achieved using activated carbon coupled with short-path distillation as has been used in the present study ${ }^{(27)}$. Other methods for removal of POP from FO are being developed, including supercritical $\mathrm{CO}_{2}$ extraction along with activated carbon $^{(37)}$. However, this methodology is equally efficient but has only been used in relatively small-scale extractions at the present time.

The cNFO diet in the present study contained $17.4 \mathrm{ng}$ TEQ/ $\mathrm{kg}$ of PCDD/F + DL-PCB and, as such, exceeds the EU maximum permitted value of $7.0 \mathrm{ng} \mathrm{TEQ} / \mathrm{kg}$ for fish feeds ${ }^{(22)}$. FO are generally considered to be the major source of PCDD/F and DL-PCB in high-energy fish diets, although a smaller contribution is derived from the fish meal component ${ }^{(14,15,24,38)}$. Despite there being considerable variation in contaminant concentrations in northern FO, due to season and location of capture, they are generally higher in PCDD/F and DL-PCB compared with those of Pacific origin ${ }^{(39,40)}$. As a result of high POP levels, a significant tonnage of FO from the North Atlantic, North and Baltic Seas would currently exceed EU permissible limits for PCDD/F + DL-PCB. Currently, oils such as the cNFO used in the present study could not be used in animal feeds and would be destroyed by high-temperature incineration. Given the nutritional value of $n-3$ HUFA as beneficial nutrients to attenuate a range of inflammatory disorders in humans ${ }^{(6,41)}$, and the fact that FO prices exceeded $\$ 1700 /$ tonne in January 2008, it seems wasteful to dispose of valuable nutrients in this way. The decontamination of the cNFO was very successful, with the dietary concentration of PCDD/F + DL-PCB falling by $97 \%$ in the deNFO diet, which was similar to the concentration of $0.53 \mathrm{ng} \mathrm{TEQ} / \mathrm{kg}$ in the $\mathrm{SFO} / \mathrm{RO} / \mathrm{SO}$ diet. This reduction in $\mathrm{PCDD} / \mathrm{F}$ and DL-PCB indicates that the efficiency of the decontamination process was consistent with reports in the literature ${ }^{(26,42)}$.

Hites et $a l .{ }^{(11)}$ reported PCDD/F + DL-PCB in Scottish farmed salmon feeds in the range $2 \cdot 5-7 \mathrm{ng} \mathrm{TEQ} / \mathrm{kg}$, with lowest values of about $1 \mathrm{ng} \mathrm{TEQ} / \mathrm{kg}$ in feed from Canada. Both the deNFO and SFO/RO/SO diets in the present study had lower levels of PCDD/F + DL-PCB compared with the Canadian feeds sampled in 2003-4. Easton et al. ${ }^{(43)}$ sampled five feeds from North America and found concentrations for DL-PCB alone in the range $1.73-10.9 \mathrm{ng} \mathrm{TEQ} / \mathrm{kg}$. The highest concentration found by Easton et al. ${ }^{(43)}$ was similar to the DL-PCB concentration in the cNFO diet (8.71 ng TEQ/kg) while the concentrations in the deNFO and SFO/RO/SO diets were $83 \%$ lower than the lowest diets sampled from North America. This clearly demonstrates the value of using either a decontaminated FO or a FO/VO blend as a means of reducing feed contaminant levels. The contaminant concentrations found in the present study, in the deNFO and SFO/RO/SO diets, are broadly similar to those seen in previous studies 
where FO has been substituted, partially or completely, with $\mathrm{VO}^{(14,15,25)}$. In a study where salmon were fed diets containing either 17 or $34 \%$ oil, which was a $100 \%$ replacement of FO with a blend of rapeseed and linseed oils, the PCDD/F + DL-PCB concentrations in the diet were 0.95 and $0.78 \mathrm{ng}$ $\mathrm{TEQ} / \mathrm{kg}$, respectively ${ }^{(25)}$. These values are about double those in the deNFO and SFO/RO/SO diets used in the present study. These differences probably reflect the use of northern fish meal in the study of Bell et al. ${ }^{(25)}$ compared with southern fish meal in the present study. Two similar studies using different levels of FO substitution were conducted by Berntssen et al. ${ }^{(13,14)}$. In the first trial, fish were fed $100 \%$ northern FO or $100 \%$ of a VO blend comprising rapeseed, linseed and palm oils for the whole production cycle. As FO content increased with pellet size, the PCDD/F + DL-PCB increased from $2.43 \mathrm{ng} \mathrm{TEQ} / \mathrm{kg}$ feed in the $0.3 \mathrm{~mm}$ pellet to $4.74 \mathrm{ng} \mathrm{TEQ} / \mathrm{kg}$ feed in the $9 \mathrm{~mm}$ pellet $^{(14)}$. In the VO diet, as the VO inclusion increased with pellet size, the PCDD/F + DL-PCB reduced from $1.07 \mathrm{ng}$ TEQ $/ \mathrm{kg}$ in the $0.3 \mathrm{~mm}$ pellet to 0.61 and $0.33 \mathrm{ng} \mathrm{TEQ} / \mathrm{kg}$ in the 6 and $9 \mathrm{~mm}$ pellets. Thus, the values for PCDD/F + DL-PCB recorded in the present study, for the deNFO and SFO/RO/ SO diets of 0.447 and $0.533 \mathrm{ng} \mathrm{TEQ} / \mathrm{kg}$, respectively, were broadly similar to the $100 \%$ VO diets used by Berntssen et al. ${ }^{(14)}$. In a second study where $100 \%$ southern FO was replaced with 30 or $60 \%$ rapeseed oil, the diet concentrations of PCDD/F + DL-PCB were 1.18, 0.93 and $0.86 \mathrm{ng} \mathrm{TEQ} / \mathrm{kg}$, respectively ${ }^{(13)}$. The value of $0.86 \mathrm{ng} \mathrm{TEQ} / \mathrm{kg}$ is slightly higher than for the SFO/RO/SO diet of $0.53 \mathrm{ng} \mathrm{TEQ} / \mathrm{kg}$, which was also a $60 \%$ replacement with VO.

The reduction of PBDE in the deNFO diet, compared with the cNFO diet, was $73 \%$, while the SFO/RO/SO diet had a $90 \%$ reduction compared with the cNFO diet, which suggested less efficient removal of PBDE compared with dioxins and PCB. However, use of activated carbon alone did not reduce $\mathrm{PBDE}$ levels in $\mathrm{FO}^{(42)}$ and so the addition of the shortpath distillation step resulted in a significant reduction in PBDE in the deNFO diet. However, the decontamination method used in the present study is less efficient for PBDE than for PCDD/F and DL-PCB. In four samples of feed from Scotland, Hites et al. ${ }^{(12)}$ reported total PBDE concentrations in the range $2 \cdot 44-10.9 \mathrm{ng} / \mathrm{g}$ wet weight while in six samples from Canada the range was $0.49-9.3 \mathrm{ng} / \mathrm{g}$. By comparison, Easton et al. ${ }^{(43)}$ measured two North American feeds which contained 1.87 and $1.90 \mathrm{ng} / \mathrm{g}$. It is noteworthy that the sum of PBDE for three of the Scottish diets and two of the Canadian diets ${ }^{(12)}$ were higher than the value of $5.94 \mathrm{ng} / \mathrm{g}$ observed in the cNFO diet. By comparison, the PBDE concentration in the deNFO diet of $1.93 \mathrm{ng} / \mathrm{g}$ is lower than nine of the feeds from Scotland, Canada and Chile analysed by Hites et al. ${ }^{(12)}$ and similar to the two feeds analysed by Easton et al. ${ }^{(43)}$. The sum of PBDE in the SFO/RO/SO diet was $0 \cdot 31 \mathrm{ng} / \mathrm{g}$, and was lower than any value reported by either Hites et al. ${ }^{(12)}$ or Easton et al. ${ }^{(43)}$.

In the present study, the PCDD/F and DL-PCB concentrations in flesh were closely correlated with diet concentrations, with the highest values in fish fed the cNFO diet (6.4 ng TEQ $/ \mathrm{kg}$ ). This value was increased compared with the initial flesh $(1 \cdot 1 \mathrm{ng} \mathrm{TEQ} / \mathrm{kg})$ but was much lower than the diet concentration. This was also observed in previous studies with salmon where the accumulation efficiency of
PCDD/F was shown to be lower than for DL-PCB ${ }^{(13,14)}$. In comparison with the fish fed the cNFO diet, the PCDD/F + DL-PCB concentrations in flesh of fish fed the deNFO and $\mathrm{SFO} / \mathrm{RO} / \mathrm{SO}$ diets were decreased compared with the initial values to 0.34 and $0.41 \mathrm{ng} \mathrm{TEQ} / \mathrm{kg}$, respectively. Although there are no data in the literature on the effects of feeding decontaminated oils, values are reported for fish fed varying levels of $\mathrm{VO}$, as well as different sources of FO. In the study by Bell et al. ${ }^{(25)}$ flesh PCDD/F + DL-PCB concentration in salmon fed a similar oil level to the present study, but where the VO was $50 \%$ rapeseed oil and $50 \%$ linseed oil, was $0.73 \mathrm{ng} \mathrm{TEQ} / \mathrm{kg}$, which was more than double the values seen in the fish fed deNFO and SFO/RO/SO in the present study. Despite having a higher level of $\mathrm{VO}$, this higher value is probably due to the use of northern fish meal in the 2005 study $^{(25)}$. The concentrations in the study by Bell et $a .^{(25)}$ are similar to those found by Berntssen et al. ${ }^{(13)}$ who reported values of 0.95 and $0.86 \mathrm{ng} \mathrm{TEQ} / \mathrm{kg}$ for fish fed either $30 \%$ or $60 \%$ rapeseed oil, respectively. The sum of ng TEQ/kg for fish fed the deNFO and SFO/RO/SO diets, in the present study, was 0.34 and $0 \cdot 41$, respectively. These values are similar to the results reported by Berntssen et al. ${ }^{(14)}$, where salmon were fed a $100 \%$ VO inclusion for 97 weeks. Although the fish in the present study were harvested at a smaller size than those produced by Berntssen et $a .^{(14)}$, it is likely that the values would decrease even more with continued culture on the deNFO and SFO/RO/SO diets. The present study lasted for only 11 weeks, while the half-life of PCDD/F and DL-PCB is estimated at approximately 5 months ${ }^{(13)}$, and an additional growth dilution would cause a continued lowering of POP loads. Thus, a further decrease in PCB levels, at least, would be expected with continued feeding on deNFO and SFO/RO/SO diets.

In the study of Hites et al. ${ }^{(11)} \mathrm{PCDD} / \mathrm{F}+\mathrm{DL}-\mathrm{PCB}$ concentrations for Scottish salmon were about $2.9 \mathrm{ng} \mathrm{TEQ} / \mathrm{kg}$ ( $n$ 30) while the concentrations in fish fed the deNFO and SFO/RO/ SO diets were about $13 \%$ of this value. In a more recent study Ikonomou et al. ${ }^{(44)}$ recorded a maximum value of 1.85 (SD 0.27) ng TEQ/kg in Canadian salmon. By comparison, the fish fed the deNFO and SFO/RO/SO diets were about $20 \%$ of this value. The mean feed PCDD/F + DL-PCB value in the Canadian diets was $3.74 \mathrm{ng} \mathrm{TEQ} / \mathrm{kg}^{(44)}$, which is 7.5 times higher than the deNFO and SFO/RO/SO diets in the present study. The PCDD/F + DL-PCB concentration for wild Pacific Chinook salmon was about $0 \cdot 13 \mathrm{ng} \mathrm{TEQ} / \mathrm{kg}^{(11)}$, while the DL-PCB values alone for a different source of Chinook salmon were about $0.45 \mathrm{ng} \mathrm{TEQ} / \mathrm{kg}^{(43)}$. Thus, the $\mathrm{PCCD} / \mathrm{F}+\mathrm{DL}-\mathrm{PCB}$ concentrations in fish fed the deNFO and SFO/RO/SO diets are only slightly higher than those quoted by Hites et al. ${ }^{(11)}$ and considerably lower than those quoted by Easton et al. ${ }^{(43)}$ for wild Pacific salmon.

The flesh PBDE concentrations for the fish fed the cNFO, deNFO and SFO/RO/SO diets were $0.94,0.25$ and $0.10 \mathrm{ng} / \mathrm{g}$, respectively. These values are all significantly lower than the values recorded for wild Canadian Chinook $(4.2 \mathrm{ng} / \mathrm{g})$, Scottish farmed $(3.9 \mathrm{ng} / \mathrm{g})$ or wild Oregon Chinook $(2.2 \mathrm{ng} / \mathrm{g})$ by Hites et $a l^{(12)}$. These values were also considerably lower than the average PBDE concentration of $5 \mathrm{ng} / \mathrm{g}$ reported by Jacobs et al. ${ }^{(45)}$ in thirteen samples of European salmon. Excluding the nine wild Chinook salmon, the average value for the thirty-six wild Pacific salmon, including Pink, Coho, 
Sockeye and Chum, was $0 \cdot 130$ (SD 0.020) ng/g ${ }^{(12)}$. The PBDE concentrations in salmon fed the deNFO and SFO/RO/SO diets were slightly higher and lower than the wild Pacific salmon, respectively.

There is currently considerable interest in fish, and especially oily fish, as a means of increasing n-3 HUFA intake in populations that currently have low fish intake. However, while the benefits of consuming $n$-3 HUFA are widely known, there is also concern about the relative risks and benefits due to the presence of POP in oily fish ${ }^{(4,14,16,46)}$ The current guideline of the UK FSA (www.food.gov.uk) suggests that we should consume up to four $140 \mathrm{~g}$ portions of oily fish per week. However, the FSA adds the caveat that girls and women of child-bearing age should only consume two $140 \mathrm{~g}$ portions of oily fish due to concerns that POP present in the fish might pose a risk to the developing fetus. Thus, for girls or women of child-bearing age, the FSA recommendation is in agreement with the EU Scientific Committee on Food that the maximum intake of PCDD/F + DL-PCB should be $2 \mathrm{pg} / \mathrm{kg}$ body weight per $\mathrm{d}^{(35)}$. However, the FSA guideline suggests that boys, men and women over reproductive age can consume up to $8 \mathrm{pg} / \mathrm{kg}$ body weight per $\mathrm{d}$. The salmon fed the cNFO diet in the present study would give $171 \%$ of the weekly limit for girls and women of reproductive age or $86 \%$ of the weekly limit value for boys, men and women over reproductive age, from two or four $140 \mathrm{~g}$ portions of $\mathrm{cNFO}$ salmon, respectively. However, salmon with these levels of POP would not be available for public consumption due to current EU limits on PCDD/F and DL-PCB in fish feeds ${ }^{(22)}$. In a sample of standard production Scottish salmon analysed in our laboratory, the average $\mathrm{PCDD} / \mathrm{F}+\mathrm{DL}-\mathrm{PCB}$ concentration in two $140 \mathrm{~g}$ portions was $493 \mathrm{pg}$ TEQ. This represents $47 \%$ of the value for girls and women of child-bearing age or $24 \%$ of the limit for boys, men and women over reproductive age. By comparison, for the deNFO and SFO/RO/SO fish, consuming two or four $140 \mathrm{~g}$ portions represents only 9.0 and $10.8 \%$ of the weekly limit for girls and women of reproductive age or 4.5 and $5.4 \%$, respectively, of the weekly limit for PCDD/F + DL-PCB for boys, men and women over reproductive age. While the POP concentrations are very low for both the deNFO and SFO/RO/SO salmon, the same two and four $140 \mathrm{~g}$ portions provide 147 and $81 \%$ and 294 and $162 \%$, respectively, of the International Society for the Study of Fatty Acids and Lipids (ISSFAL) recommended weekly intake of $\mathrm{EPA}+\mathrm{DHA}^{(8)}$.

In summary, the present study has confirmed that $\mathrm{FO}$ with high POP concentrations can be successfully decontaminated with removal of more than $97 \%$ of PCDD/F and DL-PCB using two-stage activated carbon and thin-film deodorisation. Removal of PBDE was less successful, with concentrations being reduced by about $70 \%$. Feeding the deNFO and SFO/ $\mathrm{RO} / \mathrm{SO}$ diets to $0.8 \mathrm{~kg}$ Atlantic salmon for 11 weeks resulted in excellent growth rates and feed conversion. Flesh PCDD/F and DL-PCB concentrations were reduced to very low levels in fish fed the deNFO and SFO/RO/SO diets, with values being similar to those seen in wild Pacific salmon, while PBDE concentrations were comparable or lower than Pacific salmon. Feeding the deNFO diet did not significantly alter the $n$ - 3 HUFA content of the fillet, as was observed in fish fed the SFO/RO/SO diet. This suggests that decontaminated
FO can be used successfully to produce salmon that are both high in $n-3$ HUFA and low in POP, although further longer-term trials should be conducted to ensure that no detrimental effects on fish performance and health occur. These results could be of significant benefit in producing highly nutritious farmed salmon that are very low in undesirables as well as utilising valuable FO that would otherwise be destroyed by incineration.

\section{Acknowledgements}

J. P. was funded by a Royal Thai Government Scholarship.

J. G. B. wrote the manuscript with assistance from all other authors especially M. H. G. B. and D. R. T.; E. A. B. was responsible for all aspects of the feeding trial including diet manufacture, fish production and sample collection; M. S., F. S. and J. R. D. were responsible for all aspects of contaminant analysis with technical advice supplied by M. H. G. B.; J. P. was responsible for lipid analysis; D. R. T. and J. G. B. were $\mathrm{PhD}$ supervisors of J. D. All authors read and approved the findings of the study.

None of the authors had a conflict of interest.

\section{References}

1. Dyerberg J, Bang HO \& Hjorne N (1975) Fatty acid composition of the plasma lipids in Greenland Eskimos. Am J Clin Nutr 28, 958-966.

2. Dewailly EE, Blanchet C, Gingras S, et al. (2001) Relations between $n-3$ fatty acid status and cardiovascular disease risk factors among Quebecers. Am J Clin Nutr 74, 603-611.

3. Dewailly EE, Blanchet C, Lemieux S, et al. (2001) n-3 Fatty acids and cardiovascular disease risk factors among the Inuit of Nunavik. Am J Clin Nutr 74, 464-473.

4. Scientific Advisory Committee on Nutrition and Committee on Toxicity (2004) Advice on Fish Consumption: Benefits and Risks. Norwich, UK: The Stationery Office.

5. Yaqoob P (2004) Fatty acids and the immune system: from basis science to clinical applications. Proc Nutr Soc 63, 89-104.

6. Young G \& Conquer J (2005) Omega-3 fatty acids and neuropsychiatric disorders. Reprod Nutr Dev 45, 1-28.

7. World Health Organization (2003) Diet, Nutrition and the Prevention of Chronic Diseases. Joint WHO/FAO Expert Consultation. WHO Technical Report Series no. 916. Geneva: WHO.

8. International Society for the Study of Fatty Acids and Lipids (2004) Report of the Sub-committee on the Recommendations for Intake of Polyunsaturated Fatty Acids in Healthy Adults. http://www.issfal.org.uk/images/stories/pdfs/PUFAIntakeReccomd FinalReport.pdf (accessed March 2009).

9. Bell JG, Henderson RJ, Tocher DR, et al. (2004) Replacement of dietary fish oil with increasing levels of linseed oil: modification of flesh fatty acid compositions in Atlantic salmon (Salmo salar) using a fish oil finishing diet. Lipids 39, 223-232.

10. Torstensen BE, Bell JG, Sargent JR, et al. (2005) Tailoring of Atlantic salmon (Salmo salar L.) flesh lipid composition and sensory quality by replacing fish oil with a vegetable oil blend. J Agric Food Chem 53, 10166-10178.

11. Hites RA, Foran JA, Carpenter DO, et al. (2004) Global assessment of organic contaminants in farmed salmon. Science $\mathbf{3 0 3}$, 226-229.

12. Hites RA, Foran JA, Schwager SJ, et al. (2004) Global assessment of polybrominated diphenyl ethers in farmed and wild salmon. Environ Sci Technol 38, 4945-4949. 
13. Berntssen MHG, Giskegjerde TA, Rosenlund G, et al. (2007) Predicting World Health Organization toxic equivalency factor dioxin and dioxin-like polychlorinated biphenyl levels in farmed Atlantic salmon (Salmo salar) based on known levels in feed. Env Toxicol Chem 26, 13-23.

14. Berntssen MHG, Lundebye A-K \& Torstensen BE (2005) Reducing the levels of dioxins and dioxin-like PCBs in farmed Atlantic salmon by substitution of fish oil with vegetable oil in the feed. Aquacult Nutr 11, 219-231.

15. Friesen EN, Ikonomou MG, Higgs DA, et al. (2008) Use of terrestrial based lipids in aquaculture feeds and the effects on flesh organohalogen and fatty acid concentrations in farmed Atlantic salmon. Environ Sci Technol 42, 3519-3523.

16. Foran JA, Good DH, Carpenter DO, et al. (2005) Quantitative analysis of the benefits and risks of consuming farmed and wild salmon. $J$ Nutr 135, 2639-2643.

17. Mozaffarian D \& Rimm EB (2006) Fish intake, contaminants, and human health. JAMA 296, 1885-1899.

18. Van den Berg M, Birnbaum L, Bosveld ATC, et al. (1998) Toxic equivalency factors (TEFs) for PCBs, PCDDs, PCDFs for humans and wildlife. Environ Health Perspect 106, $775-792$.

19. Van den Berg M, Birnbaum L, Denison M, et al. (2006) The 2006 World Health Organisation re-evaluation of human and mammalian toxic equivalency factors for dioxins and dioxinlike compounds. Toxicol Sci 93, 223-241.

20. North Sea Task Force (1993) North Sea Quality Status Report. London: OSPAR Secretariat.

21. De Wit C (2002) An overview of brominated flame retardants in the environment. Chemosphere 46, 583-623.

22. European Commission (2006) Commission Directive 2006/13/ EC of 3rd February 2006 amending Annexes 1 and II to Directive 2002/32/EC of the European Parliament and of the Council on undesirable substances in animal feed as regards dioxins and dioxin-like PCBs. J Eur Commun L32, 44-53.

23. European Commission (2006) Commission regulation (EC) no. 199/2006 of 3rd February 2006 amending regulation (EC) no. 466/2001 setting maximum levels for certain contaminants in foodstuffs as regards dioxins and dioxin-like PCBs. $J$ Eur Commun L32, 34-38.

24. Jacobs MN, Ferrario J \& Byrne C (2002) Investigation of polychlorinated dibenzo- $p$-dioxins dibenzo- $p$-furans and selected coplanar biphenyls in Scottish farmed Atlantic salmon (Salmo salar). Chemosphere 47, 183-191.

25. Bell JG, McGhee F, Dick JR, et al. (2005) Dioxin and dioxinlike polychlorinated biphenyls (PCBs) in Scottish farmed salmon (Salmo salar): effects of replacement of dietary marine fish oil with vegetable oils. Aquaculture 243, 305-314.

26. Maes J, De Meulenaer B, Van Heerswynghels P, et al. (2005) Removal of dioxins and PCB from fish oil by activated carbon and its influence on the nutritional quality. $J$ Am Oil Chem Soc 82, 593-597.

27. Breivik H \& Thorstad O (2005) Removal of organic environmental pollutants from fish oil by short-path distillation. Lipid Technol 17, 55-58.

28. National Research Council (1993) Nutrient Requirements of Fish. Washington, DC: National Academy Press.

29. United States Environmental Protection Agency (1994) Method 1613: 'Tetra- through Octa Chlorinated Dioxins and Furans by Isotope Dilution HRGC/HRMS', EPA no. 821B94005, October 1994. Washington, DC: Environmental Protection Agency.

30. United States Environmental Protection Agency (1999) Method 1668 rev. A: 'Chlorinated Biphenyl Congeners in Water, Soil, Sediment and Tissue by HRGC/HRMS.': EPA no. 821R00002
December 1999. Washington, DC: United States Environmental Protection Agency.

31. Folch J, Lees M \& Sloane Stanley GH (1957) A simple method for the isolation and purification of total lipides from animal tissues. J Biol Chem 226, 497-509.

32. Christie WW (1993) Preparation of derivatives of fatty acids for chromatographic analysis. In Advances in Lipid Methodology Two, pp. 69-111 [WW Christie, editor]. Dundee: The Oily Press.

33. Tocher DR \& Harvie DG (1988) Fatty acid compositions of the major phosphoglycerides from fish neural tissues: $(n-3)$ and $(n-6)$ polyunsaturated fatty acids in rainbow trout (Salmo gairdneri, L.) and cod (Gadus morhua) brains and retinas. Fish Physiol Biochem 5, 229-239.

34. Ackman RG (1980) Fish lipids. In Advances in Fish Science and Technology, pp. 87-103 [JJ Connell, editor]. Farnham, UK: Fishing News Books.

35. Scientific Committee on Food (2001) Update of the risk assessment of dioxins and dioxin-like PCBs in food based on new scientific information available since adoption of the SCF opinion of 22nd November 2000. Opinion of the Scientific Committee on Food, adopted on May 30th 2001. European Commission for Health and Consumer Protection DirectorateGeneral, Brussels, Belgium. http://europa.eu.int/comm/food/fs/ sc/scf/index_en.html (accessed April 2004).

36. Hilbert G, Lillemark L, Balchen S, et al. (1998) Reduction of organochlorine contaminants from fish oil during refining. Chemosphere 37, 1241-1252.

37. Kawashima A, Watanabe S, Iwakiri R, et al. (2009) Removal of dioxins and dioxin-like PCBs from fish oil by countercurrent supercritical $\mathrm{CO}_{2}$ extraction and activated carbon treatment. Chemosphere 75, 788-794.

38. NORA - Nordisk Atlantsamarbejde (2003) Dioxin and dioxinlike PCB in four commercially important pelagic fish stocks in the North East Atlantic Ocean. http://www.nora.fo/docs/Dioxin Final_report.pdf (accessed March 2006).

39. Isosaari P, Kiviranta H, Lie $\varnothing$, et al. (2004) Accumulation and distribution of PCDD, PCDF, and PCB congeners in Atlantic salmon (Salmo salar). Environ Toxicol Chem 23, 1672-1679.

40. Lundebye AK, Berntssen MHG, Lie $\varnothing$, et al. (2004) Dietary uptake of dioxins (PCDD/PCDFs) and dioxin-like PCBs in Atlantic salmon (Salmo salar). Aquacult Nutr 10, 199-207.

41. Kris-Etherton PM, Harris WS \& Appel LJ (2002) Fish consumption, fish oil, omega-3 fatty acids, and cardiovascular disease. Circulation 104, 2158-2163.

42. Oterhals $\AA$, Solvang M, Nortvedt R, et al. (2007) Optimization of activated carbon-based decontamination of fish oil by response surface methodology. Eur J Lipid Sci Technol 109, 691-705.

43. Easton MDL, Luszniak D \& Von der Geest E (2002) Preliminary examination of contaminant loadings in farmed salmon, wild salmon and commercial salmon feed. Chemosphere 46, 1053- 1074.

44. Ikonomou MG, Higgs DA, Gibbs M, et al. (2007) Flesh quality of market-size farmed and wild British Columbia salmon. Environ Sci Technol 41, 437-443.

45. Jacobs MN, Covaci A \& Schepens P (2002) Investigation of selected organic pollutants in farmed Atlantic salmon (Salmo salar), salmon aquaculture feed, and fish oil components of the feed. Environ Sci Technol 36, 2797-2805.

46. European Food Safety Authority (2005) Opinion of the CONTAM Panel Related to the Safety Assessment of Wild and Farmed Fish. The EFSA Journal 236. http://www.efsa.eu.int/science/contam/ contam_opinions/1007_en.html (accessed July 2005). 